\author{
Agnieszka RODAK ${ }^{1}$ \\ Opiekun naukowy: Paweł ZIOBRO², Dorota WIĘCEK ${ }^{3}$ \\ DOI: https://doi.org/10.53052/9788366249844.16
}

\title{
INNOWACYJNE METODY SZKOLEŃ OPERATORÓW W ORGANIZACJACH
}

\begin{abstract}
Streszczenie: Celem artykułu jest przedstawienie zasadności szkoleń stanowiskowych z punktu widzenia organizacji. Zostały przybliżone tradycyjne metody kształcenia operatorów $\mathrm{z}$ podziałem na zewnętrzne $\mathrm{i}$ wewnętrzne, a także innowacyjne, takie jak cieszący się coraz większą popularnością e - learning czy technologia VR.
\end{abstract}

Słowa kluczowe: Szkolenia stanowiskowe, Metody kształcenia, Innowacyjność

\section{INNOVATIVE TRAINING METHODS FOR OPERATORS IN ORGANIZATIONS}

Summary: The aim of the article is to present the validity of position training from the point of view of the organization. The traditional methods of operator education were presented, divided into external and internal, as well as innovative ones, such as the increasingly popular e-learning and VR technology.

Keywords: Position training, Learning methods, Innovation

\section{Istota szkoleń w organizacji}

Szkolenie pracowników jest nieodłączną częścią działania każdej organizacji. Niezależnie od tego czy wdrażana jest do firmy nowo przyjęta osoba, czy poszerzane są umiejętności dotychczasowej kadry, musi ono zostać przeprowadzone. Jednak często zdarza się tak, że firmy pochodzą do kwestii szkoleń z niechęcią i o ile przeszkolenie nowego operatora jest niezbędne to z resztą zespołu już bywa różnie. Często najwyższe kierownictwo rezygnuje $\mathrm{z}$ dodatkowych szkoleń pracowniczych, uważając je za stratę czasu i ,zło konieczne”. Nic bardziej mylnego. Tajemnica

\footnotetext{
1 Akademia Techniczno-Humanistyczna w Bielsku-Białej, Wydział Budowy Maszyn i Informatyki, Specjalność: Systemy logistyczne przedsiębiorstwa, email: agnieszka.rodak.121@gmail.com

${ }^{2}$ Właściciel firmy ZPT, email: pawel.ziobro@zp-team.pl

${ }^{3}$ dr inż., Akademia Techniczno-Humanistyczna w Bielsku-Białej, Wydział Budowy Maszyn i Informatyki, email: dwiecek@ath.bielsko.pl
} 
sukcesu prężnie rozwijających się przedsiębiorstw tkwi właśnie w profesjonalnym podejściu do rozwoju pracowników. W dzisiejszych czasach wszystko (czyli również gospodarka) oparte jest na wiedzy, dlatego to właśnie zasób posiadanych przez firmę informacji w dużym stopniu kształtuje jej przewagę konkurencyjną na rynku. W konsekwencji organizacjom coraz bardziej zależy na pozyskaniu pracowników mających wiedzę oraz tych, którzy chcą tę wiedzę pogłębiać, rozwijać się.

Według raportu Ipsos, przeprowadzonego na zlecenie Nowoczesnej Firmy i zamieszczonego w kompendium „Szkolenia w Polsce” aż 90\% przedsiębiorstw zatrudniających w swoich firmach powyżej 9 osób, organizuje dla swoich pracowników szereg różnorakich szkoleń [13]. Ciekawą informacją może być fakt, że do firm, w których szkolenia organizowane są regularnie, wpływa kilka razy więcej $\mathrm{CV}$ niż do tych, które na rozwój pracownika nie stawiają.

Natomiast zaniechanie rozwoju pracowników odbija się nie tylko na mniejszym przypływie nowych osób do firmy (negatywna opinia firmy w środowisku jako „takiej która nie stawia na rozwój własnej kadry"), ale również na produktywności. Nierzadko problemy z awaryjnością maszyn, wpływające na mniejszą wydajność przedsiębiorstwa, wynikają z błędów operatorów, które są skutkiem niewłaściwego przeszkolenia.

Wg badań prowadzonych w krajowym przemyśle przez Lean Enterprise Institute Polska, jedną z najważniejszych przyczyn postojów i awarii maszyn jest właśnie niedoszkolenie, bądź niewłaściwe przeszkolenie operatorów maszyn, choć często błędnie jako przyczynę przestoju w takim wypadku wskazuje się przyczyny techniczne [11].

Przedmiotem tych badań była analiza przyczyn postojów podczas procesu automatycznego montażu na wtryskarkach. Mimo że wyniki obrazowały, iż główną przyczyną była awaria podajnika, to po głębszym przyjrzeniu się okazało się, że problem leżał głębiej. Podajnik psuł się przez nieprawidłowe jego czyszczenie, co z kolei oznaczało że pracownik został niewłaściwie przeszkolony. Badanie pokazało zasadność szkoleń stanowiskowych, a także niezbędnych usprawnień tego procesu. Warto wspomnieć również jak szkolenia $\mathrm{w}$ organizacji wpływają na morale pracowników. Dzisiaj liczy się pracownik, jego potrzeby i oczekiwania względem firmy, dzięki czemu wykazuje się on większą motywacją a także zaangażowaniem w pracy. To z kolei przekłada się na lepszy stopień realizacji jego zawodowych obowiązków [10]. Szkolenia są czynnikiem motywującym dla pracowników, gdyż częściowo zaspokajają potrzebę samorealizacji. Bywają też bodźcem dla pracowników do dalszego, już samodzielnego rozwoju. Cykliczne szkolenia w organizacji widocznie poprawiają morale pracowników a także atmosferę panującą w przedsiębiorstwie. Uczestnicy szkolenia czują, że firma dba o ich rozwój. Dodatkowo więzi, które nawiążą się podczas pracy zespołowej, mają szansę zmniejszyć liczbę konfliktów między pracownikami.

\section{Metody szkoleń w organizacjach}

Istnieje wiele podziałów metod szkoleniowych. Ten najbardziej podstawowy (Rys.1) obejmuje rozróżnienie na doskonalenie pracowników w miejscu pracy (ang. on the job training) oraz poza nim (ang. off the job training): 


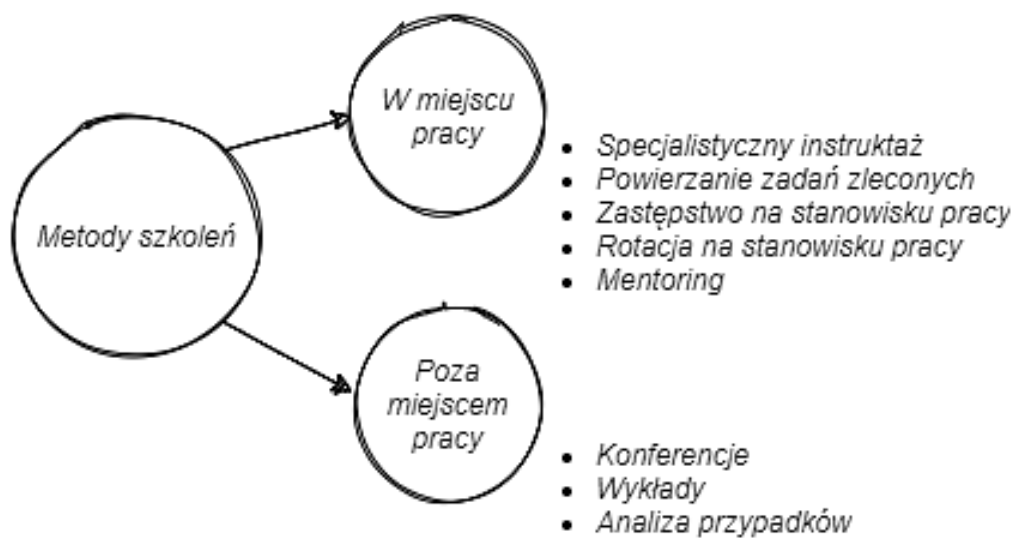

Rysunek 1. Podziat szkoleń ze względu na miejsce odbywania się szkolenia (opracowanie wtasne na podstawie [4])

\subsection{Szkolenia wewnętrzne}

Celem szkolenia na stanowisku pracy jest przekazywanie wiedzy, rozwój umiejętności i kształtowanie zachowań pracowników podczas wykonywania zadań na zajmowanym stanowisku pracy przy współpracy $\mathrm{z}$ przełożonymi. Ten rodzaj szkolenia określa się również mianem treningu poprzez pracę (ang. learning by doing). Poszczególne metody szkolenia wewnętrznego zostały opisane poniżej.

- Specjalistyczny instruktaż. Ma zastosowanie najczęściej w sytuacji gdy pracownik jest nowy lub zmienia stanowisko. Instruktaż dotyczy bardzo dokładnego zapoznania osoby szkolonej z jego zadaniami na nowym stanowisku. Osobą szkolącą może być przełożony szkolonego lub pracownik, czasami jest to pisemna instrukcja. Instruktaż rozpoczyna się od przygotowania stanowiska pracy, a szkolony operator dostaje narzędzia i materiały potrzebne do wykonywania dalszej pracy. Potem sprawdzana jest jego dotychczasowa wiedza, po czym, jeśli wypada pozytywnie, pracownik może zacząć wykonywać zadaną pracę. Kluczem jest tu sukcesywne powtarzanie wykonywanej pracy, aż do jej opanowania oraz niezbędna kontrola szkolonego operatora przez osobę bardziej doświadczoną. Odmianą tej metody jest zaprogramowany instruktaż, w której szkoli program komputerowy.

- Powierzanie zadań zleconych. Ta metoda kształcenia polega na zlecaniu pracownikowi do wykonania pewnych zadań, wykraczających poza zakres jego rutynowych obowiązków [3]. Powierzając pracownikowi zadania należy pamiętać o ustaleniu celu i terminu realizacji oraz sprawdzeniu, czy ustalony wcześniej cel został osiągnięty. Takie zadania mogą dotyczyć problemów o różnej tematyce, a dzięki nim pracodawca jest w stanie się więcej dowiedzieć o szkolonym oraz sprawdzić go w trudnych, bądź nietypowych sytuacjach.

- Zastępstwo na stanowisku pracy. Metoda ta jest podobna do wyżej wspomnianego powierzania zadań zleconych. Tutaj też sprawdzana jest przydatność pracownika na nowym stanowisku, w innych warunkach. Jednak powody są zgoła inne zazwyczaj są nimi choroby czy urlopy pracujących na tym stanowisku ludzi. 
Czasem przełożony świadomie przenosi podwładnego gdzieś indziej, poszerzając mu zakres obowiązków jednak zawsze najpierw udziela mu dokładnych wskazówek, co i jak ma wykonywać. Zastępstwo zwykle dotyczy stanowisk na tym samym poziomie lub ojeden szczebel wyższym w hierarchii organizacyjnej [5].

- Rotacja na stanowisku pracy, czyli zmiana zajmowanych stanowisk przez wybranych pracowników lub w zakresie danej grupy pracowniczej. Zmiana ta jest czasowa, ale zawsze wcześniej planowana (przełożony musi dokładnie określić na których stanowiskach będzie przeprowadzana rotacja, oraz jak długo będzie trwała). Celem rotacji jest rozszerzenie kwalifikacji pracownika oraz zwiększenie jego elastyczności (szkolony pracownik uczy się mierzyć z nowymi wyzwaniami na zupełnie innym stanowisku), a metoda ta może być stosowana na wszystkich szczeblach struktury organizacyjnej danej firmy. Dzięki temu szkolona osoba, przenoszona $\mathrm{z}$ jednego działu do drugiego, poznaje relacje pomiędzy poszczególnymi osobami w organizacji oraz procesy zachodzące $\mathrm{w}$ firmie.

- Mentoring. Osoba z dużym doświadczeniem i sukcesami zawodowymi podejmuje się wprowadzenia do firmy nowego pracownika (występują tu pewne analogie do relacji mistrz - uczeń). Bardziej doświadczony specjalista, który cieszy się powszechnym autorytetem w przedsiębiorstwie, inspiruje do nauki młodszych i mniej doświadczonych kolegów. Dając przykład, pozwala im w ten sposób lepiej odnaleźć się w firmowej rzeczywistości [1].

\subsection{Szkolenia zewnętrzne}

Szkolenia zewnętrzne (ang. off the job training) to szkolenia przeprowadzane poza stanowiskiem pracy. Techniki te są wykorzystywane do przekazywania wiedzy teoretycznej oraz nauczania określonych zachowań. Natomiast praktyczne wykorzystanie zdobytych informacji następuje dopiero po zakończeniu szkolenia.

- Konferencje, to metoda szkoleń zewnętrznych polegająca na dyskusji na określone tematy, najczęściej w małej grupie ludzi. Konferencje organizuje się zazwyczaj dla kierowników i grup specjalistów, ale udział w nich biorą również osoby z zewnątrz, np. doradcy czy naukowcy. W czasie konferencji pracownicy firmy prezentują referaty związane ze swoją pracą, pomysłami, często także wyniki najnowszych badań w jakiejś dziedzinie. Pracownicy firmy dzięki konferencjom poszerzają swoją wiedzę, nawiązują kontakty z ekspertami, a także lepiej się integrują. Jednak metoda ta jest czasochłonna i wymaga często dalekich podróży, co może (ale nie musi) działać na jej niekorzyść w porównaniu do innych technik.

- Natomiast wykłady polegają na ustnym przekazaniu odpowiednio dobranych informacji, faktów oraz opinii przez wykładowcę oraz ich przyswojeniu przez uczestników szkolenia. Odmianą tej techniki jest wykład interaktywny. Tutaj osoby szkolone same dochodzą do pewnej wiedzy i rozwiązań. Chociaż są kierowani pytaniami oraz wskazówkami osoby prowadzącej wykład, to jednak wypowiadają się na podstawie własnych doświadczeń i zgodnie z posiadanymi kompetencjami [6].

- Kolejną metodą jest analiza przypadków (ang. case study). Jest to analiza rzeczywistych bądź fikcyjnych przypadków. Na podstawie określonych sytuacji w firmie formułuje się problemy, analizuje je, a następnie szuka się 
konstruktywnych rozwiązań. Podane rozwiązania muszą zostać dokładnie sprawdzone, po to aby szkoleni pracownicy nauczyli się postępowania w nietypowych sytuacjach, wymagających zaangażowania $\mathrm{z}$ ich strony. Przypadki, które są analizowane często wzoruje się na sytuacji rzeczywistej, mającej miejsce w przeszłości bądź występującej aktualnie w danej firmie.

\section{Innowacyjne metody szkolenia pracowników}

Obecnie coraz częściej tradycyjne szkolenia organizowane dla kadry pracowniczej, wypierane są przez nowatorskie, a często także niekonwencjonalne metody (Rys.2).

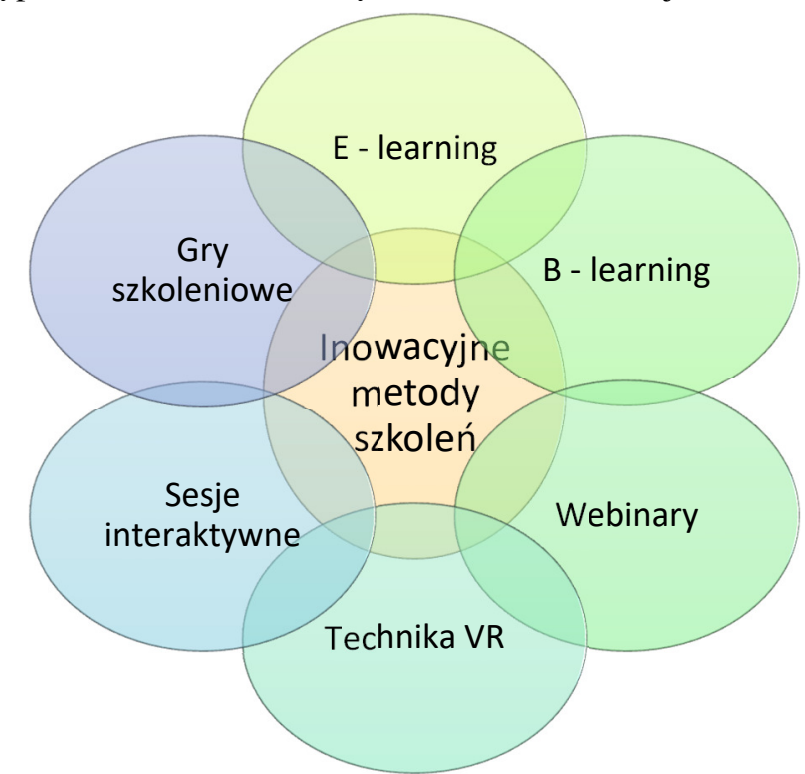

Rysunek 2. Innowacyjne metody szkoleń (opracowanie własne na podstawie [2, 9, 10, 13])

Dzieje się tak, ponieważ rozwój technologiczny dostarczył odpowiednich narzędzi, dzięki którym szkolić można się już nawet we własnym domu, za pomocą Internetu. Drugim powodem rezygnacji przedsiębiorstw z tradycyjnych form szkoleń było rozprzestrzenienie się po całym świecie wirusa COVID_19. Zmusiło to firmy do poszukiwania takich metod szkoleń, które nie wymagają fizycznej obecności pracowników (żeby nie narażać ich na zachorowanie), a jednocześnie są tak samo skuteczne jak kształcenie tradycyjnymi technikami.

\subsection{Szkolenia z wykorzystaniem nowych technologii}

Przykładem tutaj może być e-learning, zwany także szkoleniem internetowym. To metoda w pełni interaktywna i oparta na aktywnym uczeniu się. Do szkolenia z wykorzystaniem techniki e-learningu potrzebny jest jedynie dostęp do komputera i Internetu, a samo kształcenie odbywa się w sposób asynchroniczny - pracownik może korzystać $\mathrm{z}$ udostępnionych materiałów online w dogodnym dla siebie miejscu i czasie. Dzięki temu następuje znaczna redukcja kosztów finansowych w organizacji, związanych np. 
z dojazdem pracownika w miejsce szkolenia, czy też kwestia kosztu wynagrodzeń osoby prowadzącej szkolenie. Do zalet takiego innowacyjnego rozwiązania możemy zaliczyć również fakt posiadania przez pracodawcę pełnego wglądu do obecnie realizowanych kursów przez poszczególnych pracowników, ich postęp, a także końcowe rezultaty. Jest to szczególnie przydatne, np. w przypadku analizy opłacalności takiego szkolenia w porównaniu z bardziej tradycyjnymi technikami. Kolejnym plusem internetowych szkoleń jest możliwość ich przeprowadzania w różnych działach w przedsiębiorstwie, w tym samym czasie i angażujących dowolną liczbę pracowników. Nie występują w tym zakresie ograniczenia. Szkolenia w trybie e-learningu w mniejszym stopniu dezorganizują funkcjonowanie przedsiębiorstwa w porównaniu z szkoleniami tradycyjnymi, które wymagają zaangażowania wielu pracowników jednocześnie bądź ich wyjazdu [13].

Odmianą e-learningu jest b-learning (ang. blended-learning). To szkolenie mieszane, łączące w sobie techniki tradycyjne (możliwość kontaktu z trenerem) i elementy e-learningu (dostęp do materiałów szkoleniowych w każdej chwili), dzięki czemu staje się ono coraz popularniejsze $\mathrm{w}$ organizacjach.

Inną, a coraz prężniej rozwijającą się metodą szkoleń są webinary. To idealne rozwiązanie, kiedy potrzeba krótkiego szkolenia. Wiedza przedstawiana jest tylko „w pigułce”. Często webinary są tylko uzupełnieniem dotychczasowej wiedzy pracowników na dany temat. Ich użyteczność sprawdziłaby się także przy wdrażaniu nowych pracowników bądź w odniesieniu do kadry zarządzającej, która, jak podkreślano, ma wysoki poziom motywacji do zdobywania wiedzy. Wskazywano także, że webinar jest szczególnie przydatny, gdy pracownicy firmy są rozproszeni w różnych lokalizacjach [9].

Zaletą webinarów, podobnie jak szkoleń e-learningowych jest fakt redukcji kosztów związanych z dojazdem pracowników na szkolenie, a także noclegów. Oszczędza się więc nie tylko pieniądze, ale również i czas. Zaznaczyć należy tutaj, że skuteczność webinarów jest porównywalną do tradycyjnych szkoleń, co również działa na korzyść tej metody. Oprócz e - learningu czy webinarów, w organizacjach stosuje się również szkolenia z wykorzystaniem technik rzeczywistości wirtualnej (VR). Technologia VR charakteryzuje się niemal całkowitym odcięciem zmysłów człowieka od bodźców pochodzących z rzeczywistego świata. W zamian za to prezentowany jest mu obraz oraz dźwięk przygotowany przez komputer, będący odzwierciedleniem symulowanego środowiska. Dzięki temu uczestnik ma wrażenie, że znajduje się w rzeczywistej sytuacji (Rys.3).

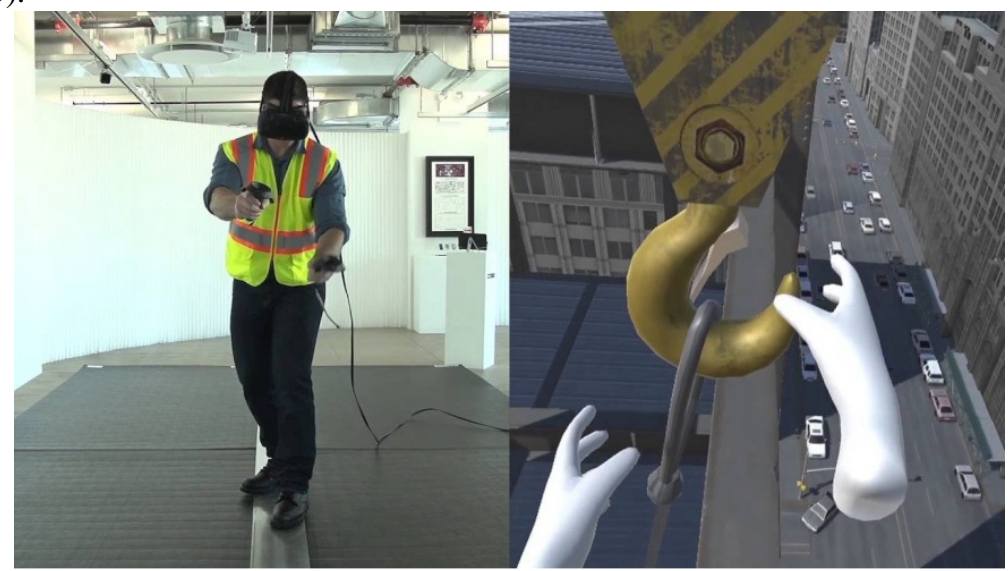

Rysunek 3. Szkolenie z wykorzystaniem techniki VR [7] 
W technologii VR wykorzystuje się (Rys.4) urządzenie zwane HMD (Head Mounted Display). HMD przypomina gogle z wyświetlaczem. Oprócz gogli dodatkowo stosowany jest system śledzenia, żeby szkolony uczestnik był w stanie poruszać się po wirtualnym środowisku. System śledzenia składa się z anteny oraz czujników rozmieszczonych na HMD oraz kończynach górnych.

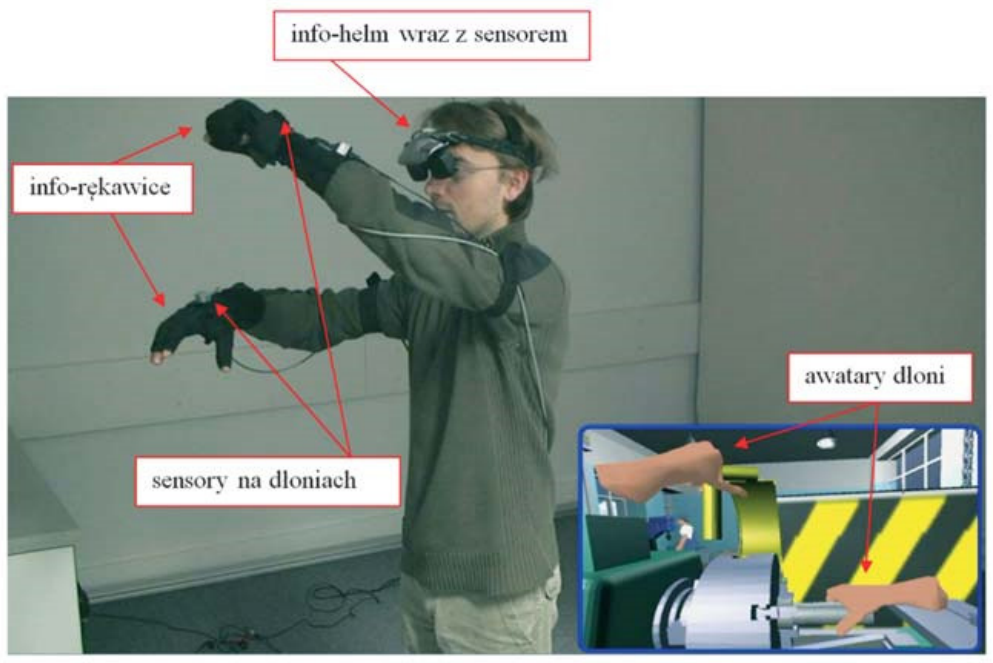

Rysunek 4. Urzadzenie HMD [2]

Korzystanie z technik rzeczywistości VR wydaje się być szczególnie przydatne w sytuacjach, gdy szkolenia w warunkach rzeczywistych wiążą się z zagrożeniem zdrowia i życia człowieka. Z tego względu szkolenia z wykorzystaniem wirtualnej rzeczywistości najczęściej związane są z takimi dziedzinami, jak medycyna (np. wirtualne operacje Rys.5), energetyka atomowa (np. ograniczenie narażenia pracownika na promieniowanie jonizujące) oraz kopalnie [2].

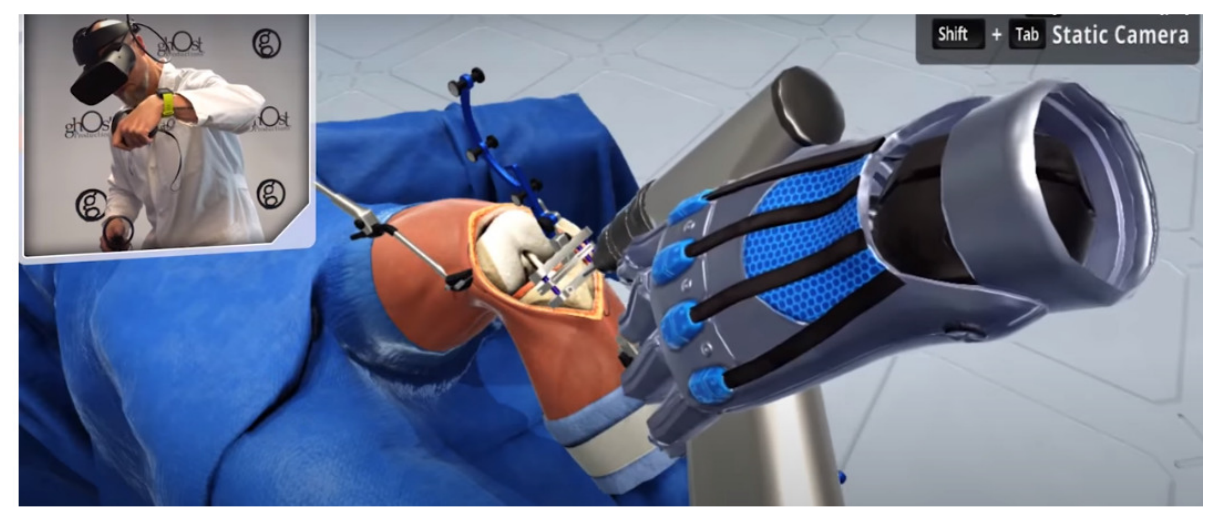

Rysunek 5. Wirtualna rzeczywistość w medycynie [8] 


\subsection{Niekonwencjonalne metody szkoleń}

Nie tylko rozwój technologiczny pozwolił inaczej spojrzeć pracodawcom na szkolenia w firmie, ale również fakty i przemawiające za nimi opinie, że innowacyjne szkolenia nie są nużące - jednocześnie bawią i uczą. Dlatego firmy stawiają na coraz nowsze, a także mniej spodziewane metody aktywizacji uczestników szkolenia.

Przykładem takiej aktywizacji jest organizowanie sesji interaktywnych zamiast tradycyjnych szkoleń. Podczas takiego szkolenia trener wchodzi w interakcję z osobami szkolonymi, próbując ich zmobilizować do dzielenia się własnymi doświadczeniami $\mathrm{z}$ danej dziedziny $\mathrm{z}$ pozostałymi uczestnikami. Pozwala to na utrzymanie skupienia uczestników oraz umożliwia im wykazanie się w danej tematyce. Interaktywne metody szkoleniowe mogą mieć bardzo wiele wersji, a wszystko zależy od rodzaju wiedzy, jaką chce przekazać szkoleniowiec oraz pomysłu, jaki ma na to szkolenie i jego przebieg. Można uatrakcyjnić kurs poprzez quiz $\mathrm{z}$ nagrodami, gdzie uczestnicy będą wykorzystywać swoją wiedzę w wewnętrznej rywalizacji. Chęć wygranej będzie motywowała ich do większego skupienia się na kursie, co znajdzie odzwierciedlenie w efektywności takiego szkolenia.

Inną, nieszablonową formą kształcenia jest również szkolenie przez udział uczestników w grach szkoleniowych, które dostarczają wiedzę i umiejętności w nieco inny sposób (Rys.6).

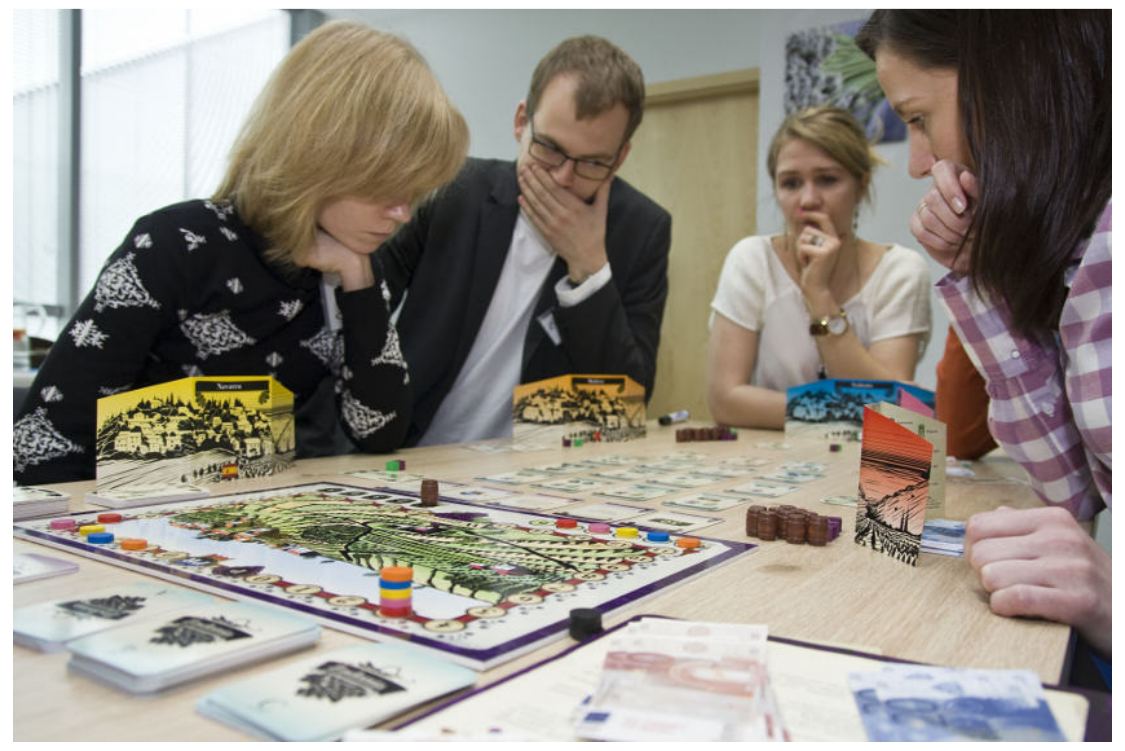

Rysunek 6. Gry szkoleniowe [12]

Okazuje się, że nauka poprzez zabawę czy atrakcyjne metody nauczania, to o wiele skuteczniejsze metody zwiększania kwalifikacji pracownika. Ten nie traktuje szkolenia jak przykrego obowiązku, ale raczej jako dodatkową korzyść, którą będzie mógł wykorzystać na wielu płaszczyznach [10]. Udział w takiej grze sprawia, że szkolenie nie jest nużące, a uczestnicy pobudzają swoją wyobraźnię, poznają się nawzajem, uczą zdrowej rywalizacji oraz pracy w zespole. Na rynku można znaleźć szeroki wybór gier 
zespołowych - jedne uczą zarządzania sobą w czasie, drugie zarządzania zespołem. Inne za to pozwalają rozwinąć umiejętności negocjacji czy współpracy w grupie.

\section{Podsumowanie}

Niewątpliwie w każdej firmie zauważalna jest potrzeba szkoleń. Jednak wybór sposobu, w jaki mają być przedstawiane treści szkoleniowe i za pomocą jakiej metody kurs ma zostać zrealizowany to dla pracodawcy niemałe wyzwanie. Dzisiaj szkolenia twarde, które polegają na przedstawieniu teorii czy konkretnych umiejętności, nie są już atrakcyjne dla uczestników. Okazuje się, że specjaliści do spraw rozwoju kadry wskazują, iż szkolenia mogą być skuteczne, jeśli będą spotykać się z zainteresowaniem kursantów i rzeczywiście będą odpowiadać na ich indywidualne potrzeby oraz możliwości. Nie chodzi tutaj jedynie o tematykę i zakres szkolenia, które to muszą być odpowiednio dobrane, biorąc chociażby pod uwagę zajmowane przez pracownika stanowisko i jego możliwości wspinania się po kolejnych szczeblach zawodowej kariery. Liczy się również forma szkolenia [10]. Im bardziej aktywizująca uczestników, tym lepiej. Wtedy szkolenie staje się efektywne. Rozwiązaniem staje się w takim przypadku wykorzystanie innowacyjnych metod kształcenia, jak coraz bardziej popularne szkolenie z goglami VR, czy też oryginalne i wyróżniające się formą sesje interaktywne bądź gry szkoleniowe. Ich zaletą jest tu nieszablonowość, będąca często niespodzianką dla uczestników i dzięki temu większe zaangażowanie ich w cały proces szkoleniowy. Niekonwencjonalne metody szkoleniowe budują doświadczenia u użytkowników, zachęcają ich do myślenia i pobudzają wyobraźnię. Efektem jest szybkie przyswajanie informacji i tym samym efektywna nauka pożądanych treści.

\section{LITERATURA}

1. GARSKI K., GONTARZ J.: Jak efektywnie szkolić pracowników. Polska Agencja Rozwoju Przedsiębiorczości, Warszawa 2009, s. 22.

2. GRABOWSKI A.: Wykorzystanie współczesnych technik rzeczywistości wirtualnej i rozszerzonej do szkolenia pracowników. Centralny Instytut Ochrony Pracy - Państwowy Instytut Badawczy, BP 04/2012, s. 18.

3. KURYŁOWICZ-RODZOCH A.: Inwestowanie w pracownika. Przegląd metod szkolenia- część I, Praca i Zabezpieczenie Społeczne, 1999, nr 7-8, s. 11.

4. MATEJEK P.: Szkolenia pracownicze w nowoczesnej organizacji. Zeszyty Naukowe Uniwersytetu Przyrodniczo-Humanistycznego w Siedlcach, Siedlce 2014, nr 100, s. 330-332.

5. SZAŁKOWSKI A. (red.): Wprowadzenie do zarządzania personelem. Wydawnictwo Akademii Ekonomicznej w Krakowie, Kraków 2000, s. 119-120.

6. Strona internetowa Avehansen. Szkolenia i Doradztwo - Metody szkoleń przegląd tradycyjnych i nowoczesnych metod szkoleniowych: https://szkolenia.avenhansen.pl/artykuly/metody-szkolen.html, 29.10.2021

7. Strona internetowa Data Driven Investor - Challenges in using Virtual Reality for Training: https://medium.datadriveninvestor.com/challenges-in-usingvirtual-reality-for-training-fea4d986faa, 04.11.2021

8. Strona internetowa Giant Lazer - VR w medycynie: https://giantlazer.com/pl/vr-w-medycynie/, 10.11.2021 
9. Strona internetowa Infor $-\mathrm{Z}$ jakich nowoczesnych form szkoleniowych korzystają polskie firmy:

https://kadry.infor.pl/poprzednie_tematy_dnia/642482,Z-jakich-nowoczesnychform-szkoleniowych-korzystaja-polskie-firmy.html, 29.10.2021

10. Strona internetowa Kariera IT - Innowacyjne metody szkolenia pracowników: http://www.karierait.pl/innowacyjne-metody-szkolenia-pracownikow/, 29.10.2021

11. Strona Internetowa LeanTrix - Szkolenia TWI. Instruktaż stanowiskowy wg metod TWI IP, kluczem do lepszej wydajności: https://leantrix.com/pl/szkolenia-stanowiskowe-wg-metod-twi-kluczem-dolepszej-wydajnosci/, 29.10.2021

12. Strona internetowa OKTI - Gry szkoleniowe w praktyce - dni otwarte: http://www.okti.pl/aktualnosci/gry-szkoleniowe-w-praktyce-dni-otwarte02062015, 10.11.2021

13. Strona internetowa Protecta - Nowoczesne metody szkolenia pracowników: https://bhp-szkolenia.info/nowoczesne-metody-szkolenia-pracownikow/, 28.10.2021 